Є. Г. Міюшкович, А. В. Гребеняк, Я. С. Парамуд Національний університет “Львівська політехніка", кафедра електронних обчислювальних машин

\title{
ТЕЛЕКОМУНІКАЦІЙНІ ПІДСИСТЕМИ КІБЕРФІЗИЧНИХ СИСТЕМ
}

\author{
() Міюшкович С. Г., Гребеняк А. В., Парамуд Я. С., 2016
}

Проаналізовано структурні рішення автономних вимірювально-обчислювальних вузлів (АВОВ) Ethernet-оріснтованих кіберфізичних систем (КФС). Показано можливість використання в них стандартних промислових сенсорів та актуаторів 3 низькошвидкісними послідовними портами. Розроблено загальні засади побудови телекомунікаційних підсистем. Запропоновано базові варіанти реалізації телекомунікаційних підсистем та розроблено рекомендації щодо вибору конкретного рішення за критерісм необхідної обчислювальної потужності для первинного опрацювання даних. Досліджено фізичну модель телекомунікаційної підсистеми.

Ключові слова: кіберфізична система, телекомунікаційна підсистема, автономний вимірювально-обчислювальний вузол, послідовний порт.

\section{TELECOMMUNICATION SUBSYSTEMS OF CYBER-PHYSICAL SYSTEMS}

(C) Miyushkovych E., Hrebenyak A., Paramud Y., 2016

This paper presents the analysis of structural solutions of autonomous measurement and computing nodes in Ethernet-centric cyber-physical systems. The possibility of using in them standard industrial sensors and actuators with low-speed serial ports was demonstrated. The general principles of building of telecommunication subsystems was proposed. Considered a few basic embodiments of telecommunication subsystems and formulated recommendations for choosing a specific decision by the criterion of necessary computing power for data preprocessing. The physical model of telecommunications subsystems was studied.

Key words: cyber-physical system, telecommunication sybsystem, autonomous measurement and computing node, serial port.

Вступ

Стрімкий розвиток комп'ютерних технологій сприяє розширенню сфер їхнього застосування. Одним із нових варіантів такого застосування є кіберфізичні системи. Проблема створення ефективних кіберфізичних систем $є$ актуальною і, відповідно, дослідження в цій царині є доцільними.

Аналіз останніх досліджень та публікацій

Багатогранність кіберфізичних систем створює передумови проведення широкого спектра досліджень стосовно підходів та засад їх побудови. Одними із останніх є дослідження професора А. Мельника, результати яких опубліковано в концептуальних наукових працях [1-3]. У роботах встановлено, що в окремих кіберфізичних системах важливими компонентами є автономні вимірювально-обчислювальні вузли (АВОВ), на які покладається первинне опрацювання даних, та телекомунікаційні засоби, основним завданням яких є забезпечення ефективного обміну інформацією. В роботі [4] досліджено концепцію застосування телекомунікаційних інтерфейсів у КФС. У роботі [5] запропонована класифікацію та особливості застосування телекомунікаційних інтерфейсів, обгрунтовано доцільність побудови телекомунікаційних складових масштабованих кіберфізичних систем на основі промислового Ethernet та/або WiFi. При цьому слід врахувати, що ці 
інтерфейси не $є$ найпоширенішими серед типових промислових засобів вимірювання та управління, які будуть підключені до автономного вимірювально-обчислювального вузла (АВОВ). Відповідно у телекомунікаційних підсистемах (ТКПС) виникає необхідність використання інтерфейсних мостів та інших раціональних структурних, алгоритмічних, схемотехнічних, програмних рішень. Тому дослідження структурних рішень ТКПС у КФС є актуальною науково-прикладною задачею.

\section{Постановка задачі}

При побудові ієрархічних Ethernet-орієнтованих КФС з серійними промисловими засобами вимірювання та управління виникає необхідність використання телекомунікаційних підсистем 3 метою інтеграції сенсорів та актуаторів, які обладнані послідовними портами (UART, RS-232, RS485, Current Loop і т.п.). У межах цієї статті буде розглянуто особливості побудови раціональних структур телекомунікаційних підсистем з врахуванням забезпечення можливості віддаленої зміни алгоритмів та програмного забезпечення первинного опрацювання даних.

\section{Основний матеріал дослідження}

Узагальнену структурну схему автономного вимірювально-обчислювального вузла Ethernetорієнтованої КФС наведено на рис. 1. Основними компонентами є телекомунікаційна підсистема, сенсори, актуатори. ТКПС складається з чотирьох основних частин: блоку комутації каналів, блоку опрацювання даних та керування, блоку віддаленого оновлення ПЗ і блоку мережних інтерфейсів.

Блок комутації каналів, окрім своєї основної функції, здійснює узгодження сигналів АВОВ та промислового обладнання на фізичному рівні. На ринку наявна широка номенклатура трансиверів для типових асинхронних послідовних інтерфейсів промислових мереж, що дає змогу підібрати необхідні як за технічними (швидкість, відстань передачі, споживана потужність), так і за економічними параметрами.

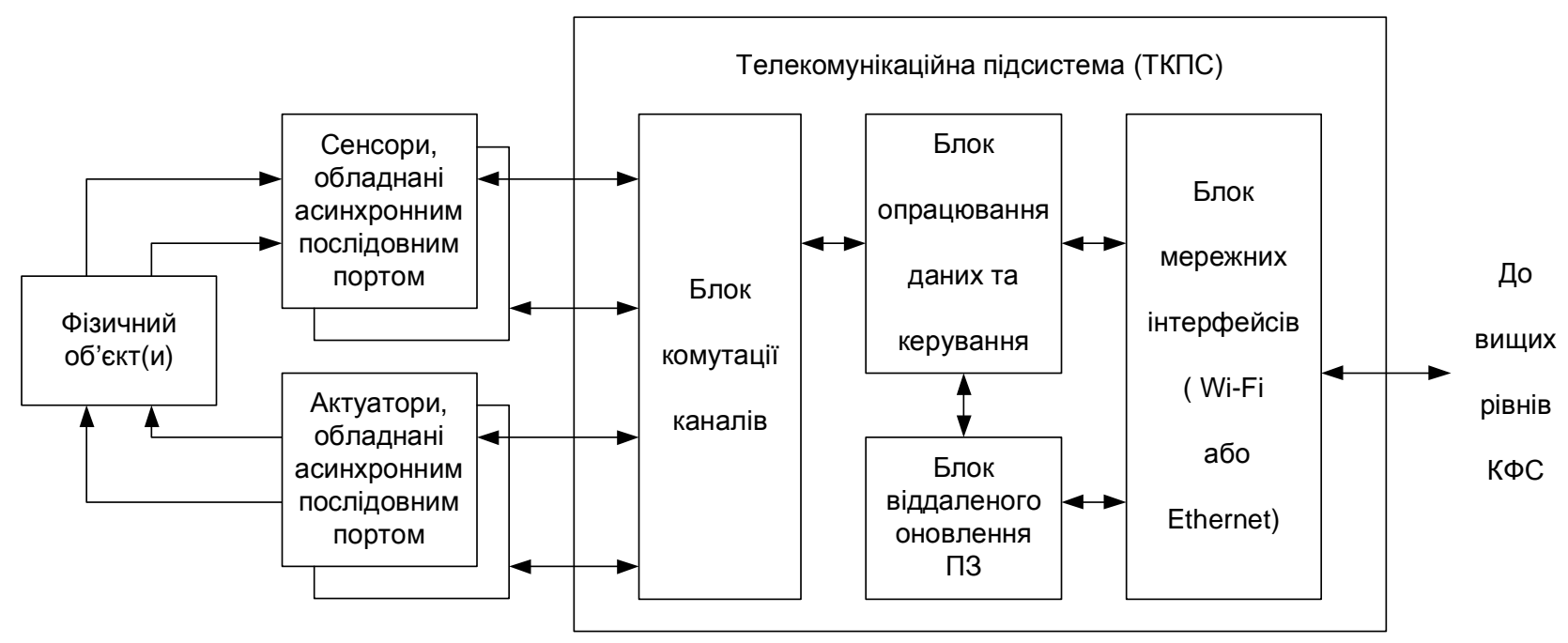

Рис. 1. Структурна схема автономного вимірювально-обчислювального вузла КФС

Взаємодія з промисловими засобами вимірювання та управління в загальному випадку $є$ двонаправленою, а тому виділення спеціалізованих каналів для сенсорів та для актуаторів $\epsilon$ недоцільним. У випадку одноканального АВОВ цей блок може скоротитися до одного трансивера.

Блок опрацювання даних та керування здійснює вибір каналу для взаємодії, первинну обробку даних від сенсорів та формування керуючих сигналів для актуаторів. Необхідна продуктивність обчислювальних засобів цього блоку визначається складністю алгоритмів обробки даних, кількістю каналів та реальною інтенсивністю інформаційного обміну.

Блок віддаленого оновлення ПЗ дає змогу замінити вбудований ПЗ блок опрацювання даних та керування. Залежно від можливостей апаратної платформи АВОВ він може бути реалізований як 
програмним шляхом, тобто у вигляді окремого програмного модуля в складі блоку керування, так i апаратним шляхом у вигляді окремого мікроконтролера.

Блок мережних інтерфейсів може бути реалізований декількома способами, переваги та недоліки яких будуть розглянуті нижче.

Логічні режими роботи телекомунікаційної підсистеми Ethernet-орієнтованої КФС основані на стеку протоколів ТСР/IP. Його повноцінна реалізація вимагає залучення доволі значних обчислювальних ресурсів, а тому вибір засобів для реалізації блока мережних інтерфейсів визначається насамперед наявністю вільних обчислювальних ресурсів в ядрі ТКПС, тобто в блоці опрацювання даних та керування.

У випадку, якщо інтенсивність інформаційного обміну між АВОВ та верхніми рівнями КФС $\epsilon$ низькою, то доцільною буде реалізація блоку мережних інтерфейсів у вигляді інтерфейсного моста.

Інтерфейсний міст доцільно реалізовувати як спеціалізовану “систему-на-кристалі” (SoC), обчислювальна потужність якої достатня для функціонування Unix-подібної ОC з закритим кодом, що забезпечує повноцінну реалізацію стеку ТCP/IP.

Базову структуру ТКПС з можливістю локального оновлення вбудованого функціонального програмного забезпечення (ПЗ) наведено на рис. 2.

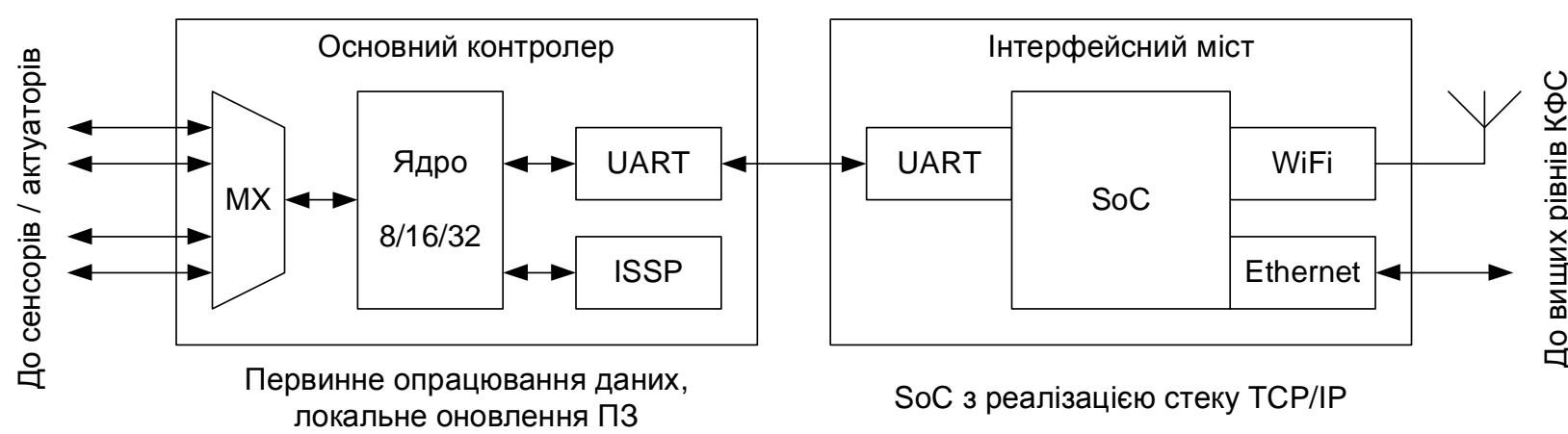

Рис. 2. ТКПС з локальним оновленням вбудованого ПЗ на основі інтерфейсного моста

Локальне оновлення вбудованого ПЗ здійснюється через послідовний порт внутрішньосхемного програмування основного контролера ISSP (In-System Serial Programming). Залежно від типу основного контролера це може бути інтерфейс JTAG, I2C, SPI, UART або інший.

Цей підхід має такі переваги:

- використання інтерфейсного моста як завершеного рішення (з реалізацією стеку ТСР/IP засобами ОС) суттєво скорочує термін розроблення та відлагодження комунікаційної підсистеми;

- можливість вибору мікроконтролера залежно від складності алгоритмів обробки даних (від 8-бітних МК до високопродуктивних DSP);

- у деяких випадках (один канал, обробка даних не потрібна) можна взагалі відмовитися від мікроконтролера, залишивши в складі ТКПС тільки трансивер та інтерфейсний міст;

До недоліків належать:

- закритість коду вбудованого ПЗ інтерфейсного моста - усунення виявлених помилок лише у нових офіційних версіях прошивок;

- використання альтернативних прошивок (напр. OpenWRT) позбавляє інтерфейсний міст гарантії виробника.

Прикладом можуть бути інтерфейсні мости UART - WiFi від Mediatek (MT7681), Marvell (88W8801), Wiznet (WizFi210), Espressif (ESP8266); модуль UART - Ethernet/WiFi HLK-RM04 та цілий ряд інших. При цьому використовуються рішення лише 3 оригінальними (офіційними) версіями вбудованого ПЗ.

Для забезпечення можливості віддаленого оновлення вбудованого ПЗ блоку опрацювання даних та керування до складу базової структури ТКПС додається окремий вузол - програматор (рис. 3). 


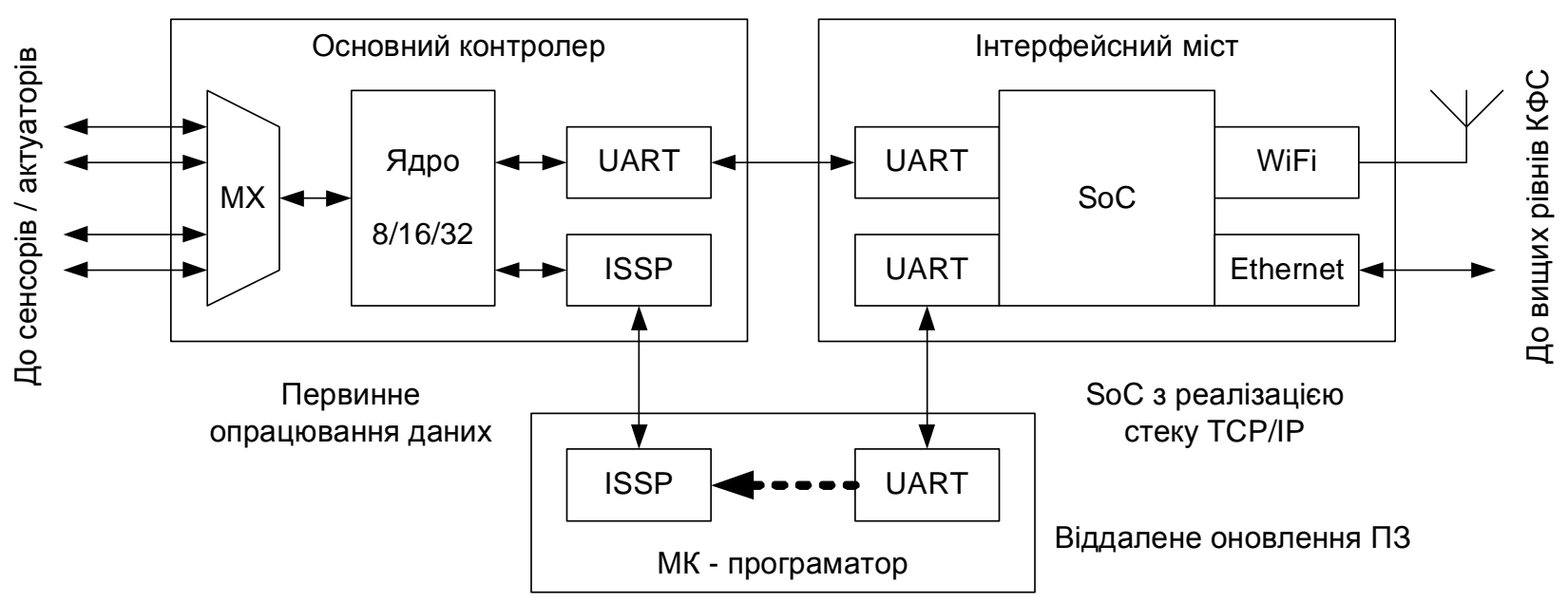

Рис. 3. ТКПС з віддаленим оновленням вбудованого ПЗ на основі інтерфейсного моста

У цьому випадку доцільним буде використання інтерфейсного моста HLK-RM04, в якому реалізовано одразу два інтерфейси UART. Вбудоване ПЗ програматора повинно бути піддане ретельному тестуванню, оскільки його відмова під час зміни основної прошивки призведе до втрати працездатності АВОВ загалом.

Перевагою такого рішення є можливість повноцінної реалізації протоколу програмування на окремому мікроконтролері, а також можливість повторного програмування основного контролера у випадку збою під час попередньої спроби.

У випадку, якщо інтерфейсний міст дозволяє реалізацію додаткового програмного функціоналу користувача на власних ресурсах (наприклад, ESP8266 з альтернативною прошивкою), стає можливою реалізація віддаленої зміни основного вбудованого ПЗ без додаткових апаратних витрат у вигляді окремого мікроконтролера-програматора. Для цього на його незадіяних виводах загального призначення (GPIO) програмним шляхом емулюється відповідний інтерфейс внутрішньосхемного програмування (ISSP). Відповідну базову структуру наведено на рис.4.

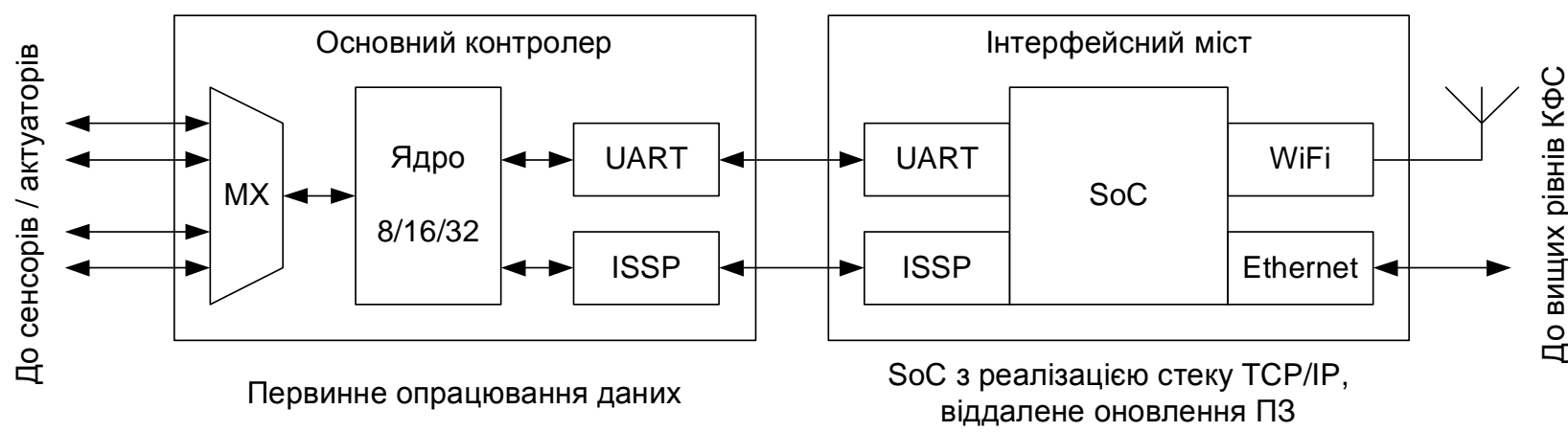

Рис. 4. ТКПС з віддаленим оновленням вбудованого ПЗ на основі модифікованого інтерфейсного моста

У випадку, якщо ядро АВОВ володіє достатньою обчислювальною потужністю, то можлива програмна реалізація стеку протоколів ТCP/IP у блоці обробки даних та керування. В цьому випадку функції блоку мережних інтерфейсів зводяться лише до забезпечення взаємодії на фізичному та канальному рівнях. Можливе використання як спеціалізованих інтерфейсних мікросхем, що забезпечують реалізацію фізичного та канального рівнів Ethernet/WiFi, так i мікроконтролерів з інтегрованим інтерфейсом фізичного рівня Ethernet (рис. 5).

Прикладом останнього може бути PIC18F67J60 виробництва Microchip. При цьому слід зауважити, що мікроконтролери 3 інтегрованим фізичним рівнем Ethernet зустрічаються порівняно рідко.

Стек протоколів зазвичай надається у вигляді пропрієтарної бібліотеки від виробника МК. 


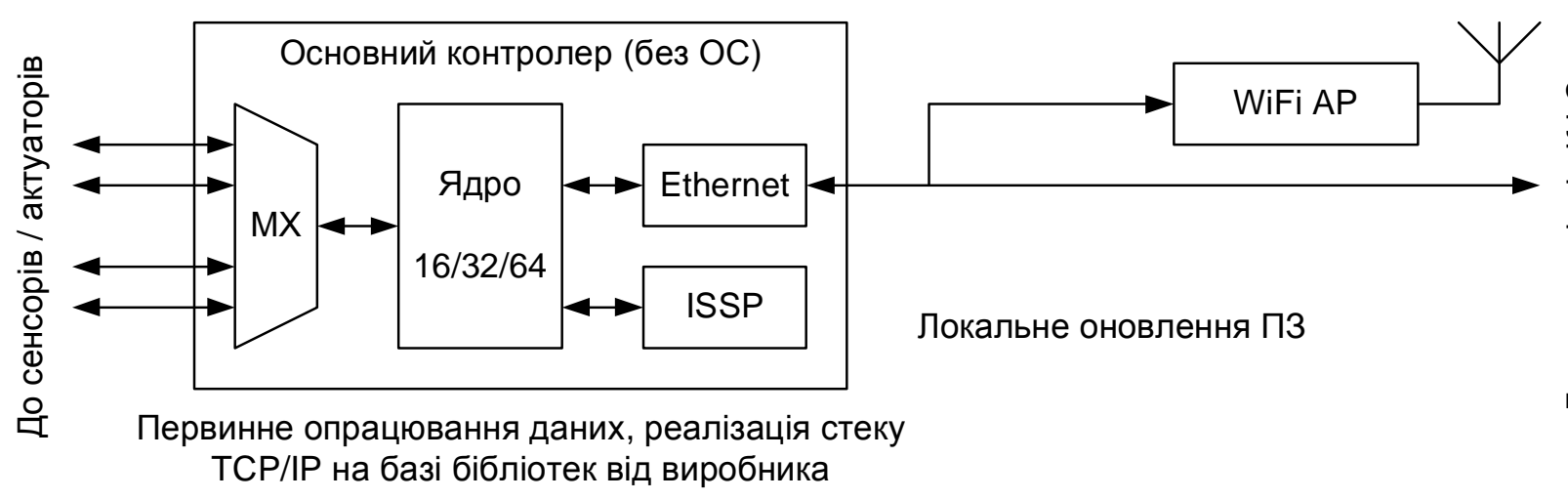

Рис. 5. ТКПС з локальним оновленням вбудованого ПЗ на базі МК

За своєю суттю цей варіант являє собою реалізацію інтерфейсного моста у вигляді відкритої апаратно-програмної платформи, всі наявні ресурси якої доступні розробнику. Функціонали блоку обробки даних та керування та блоку мережних інтерфейсів реалізуються на спільному обчислювальному ядрі, що висуває підвищені вимоги під час розроблення вбудованого ПЗ.

Розглянуте структурне рішення має такі переваги:

- мінімізація апаратних витрат;

- за достатньої продуктивності МК можливе досягнення суттєво більшої інтенсивності інформаційного обміну з вищими рівнями КФС порівняно з варіантами на основі закритого інтерфейсного моста.

До недоліків належать:

- підвищена складність створення вбудованого ПЗ;

- пропрієтарна бібліотека стеку ТCP/IP з закритим вихідним кодом зазвичай $є$ платною;

- часто з метою економії обчислювальних ресурсів реалізується лише частина стеку TCP/IP;

- будь-які зміни в алгоритмі функціонування ПЗ вимагають перепрошивки МК, що не завжди можна реалізувати у віддаленому варіанті, оскільки ядро в момент зміни вбудованого ПЗ повинно підтримувати зв'язок з джерелом прошивки.

Останній недолік можна усунути, ввівши до складу такої ТКПС окремий апаратний модуль програмування з таким алгоритмом роботи: спочатку бінарна версія оновленого вбудованого ПЗ завантажується у локальну пам'ять модуля програмування, а згодом він ініціює сеанс перепрошивки основного. Базову структуру такого рішення наведено на рис.6.

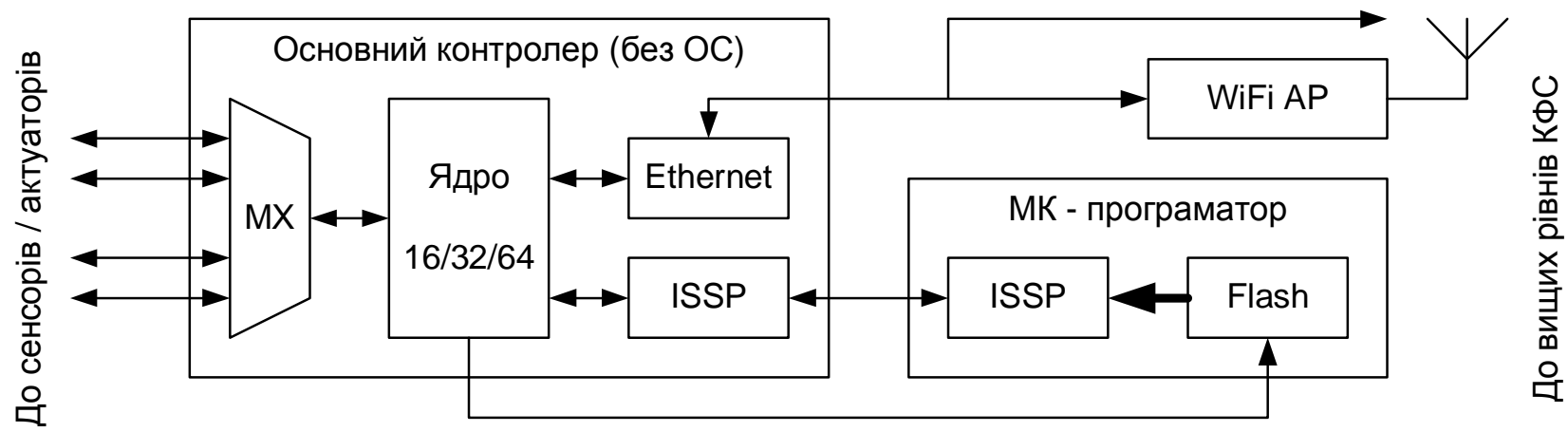

Первинне опрацювання даних, реалізація стеку TCP/IP на базі бібліотек від виробника

Віддалене оновлення ПЗ

Рис. 6. ТКПС з віддаленим оновленням вбудованого ПЗ на основі МК

Недоліком такої схеми віддаленої зміни вбудованого ПЗ є втрата функціональності АВОВ у випадку збою в процесі перепрограмування, оскільки встановлення зв'язку для повторного завантаження прошивки програматором буде неможливим. 
У випадках, якщо необхідна складна обробка даних, має місце висока інтенсивність інформаційного обміну $з$ вищими рівнями КФС, можлива часта зміна алгоритмів обробки чи потрібна повноцінна реалізація стеку ТCP/IP, доцільно перейти до рішень вищого рівня, тобто до застосування одноплатних мікроЕОМ.

Достатньо продуктивна одноплатна мікроЕОМ з повноцінною ОС через інтерфейс USB може бути доповнена відповідними мережними адаптерами (рис.7). Типовими представниками даного підходу є одноплатні мікроЕОМ серії Raspberry Pi (моделі А, A+, B, B+, 2B, Zero).

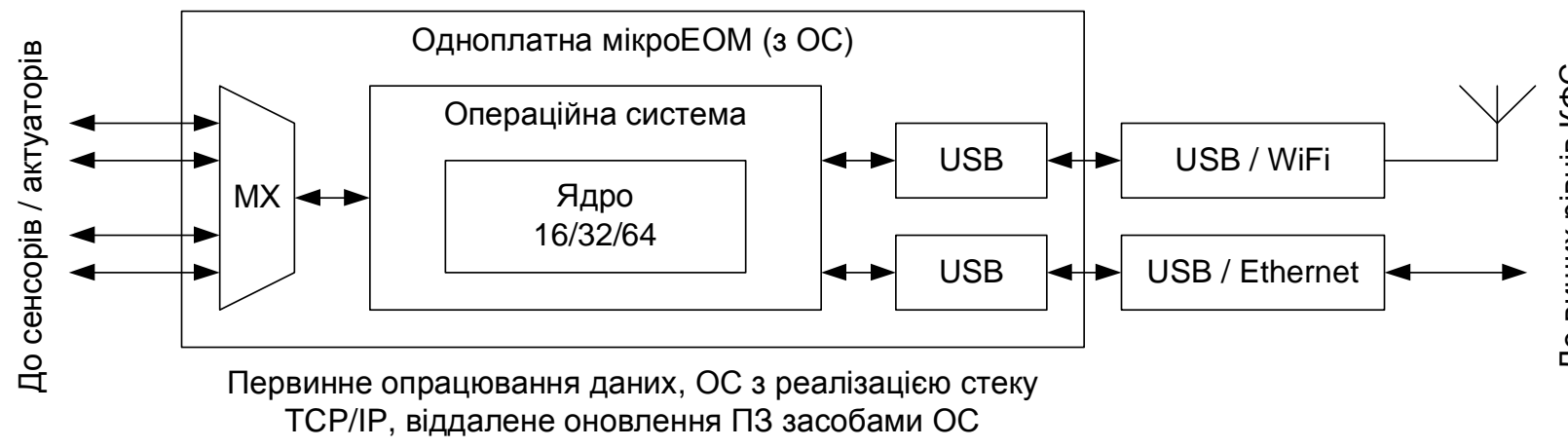

Рис. 7. ТКПС на основі одноплатної мікроЕОМ з інтегрованим інтерфейсом USB

Можливе також використання одноплатних мікроЕОМ $з$ інтегрованим інтерфейсом Ethernet або WiFi (рис. 8). Типовим представником даного підходу є одноплатна мікроЕОМ Raspberry Pi 3.

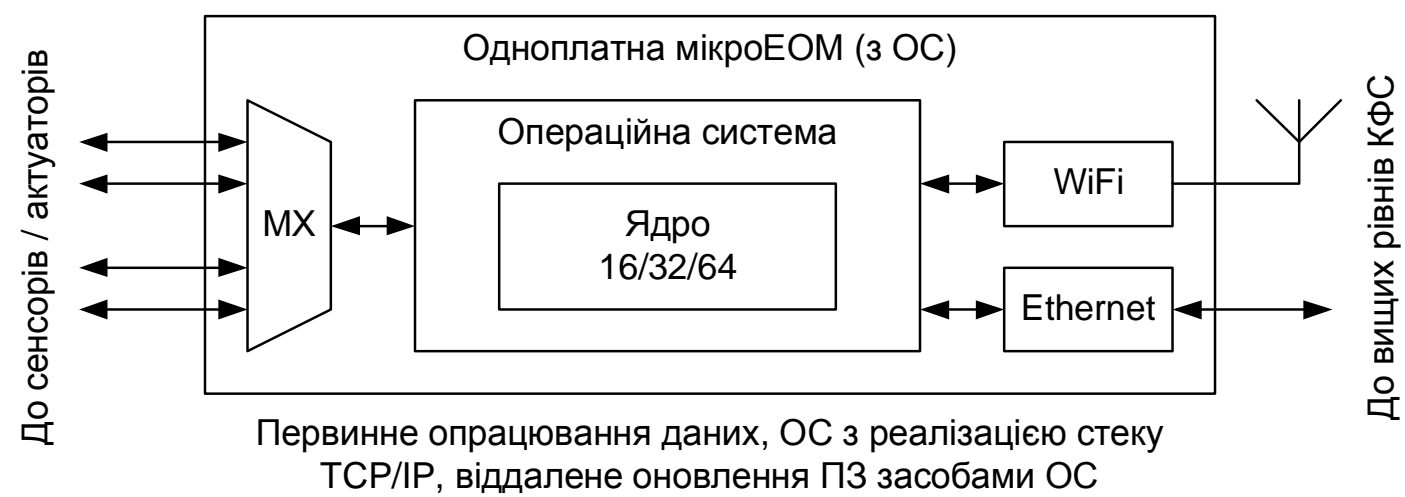

Pис. 8. ТКПС на основі одноплатної мікроЕОМ з інтегрованим інтерфейсом Ethernet або WiFi

Ці підходи мають такі переваги:

- можливість встановлення ОС з відкритим вихідним кодом;

- гнучкість при виборі типів та кількості інтерфейсів;

- зміна алгоритмів обробки даних засобами ОС.

До недоліків можна віднести наступне:

- підвищене енергоспоживання;

- додаткова витрати ресурсів процесора на підтримку ОС загалом та зокрема достатньо складного в реалізації інтерфейсу USB.

Частковим випадком цього підходу можна вважати використання стандартного промислового ПК (РС-104, PCI-104 і т.п.) із відповідними платами інтерфейсних розширень. Особливістю цього варіанта $є$ можливість реалізації ТКПС в індустріальному виконанні, але ціна такого рішення буде суттєво вищою, ніж у попередніх випадках.

\section{Експериментальна перевірка}

3 метою перевірки можливості практичної реалізації розглянутих вище варіантів побудови було зібрано декілька експериментальних фізичних моделей, зокрема ТКПС 3 локальним оновленням вбудованого ПЗ на базі програмованого інтерфейсного моста. 
Структурну схему фізичної моделі ТПКС наведено на рис. 9.

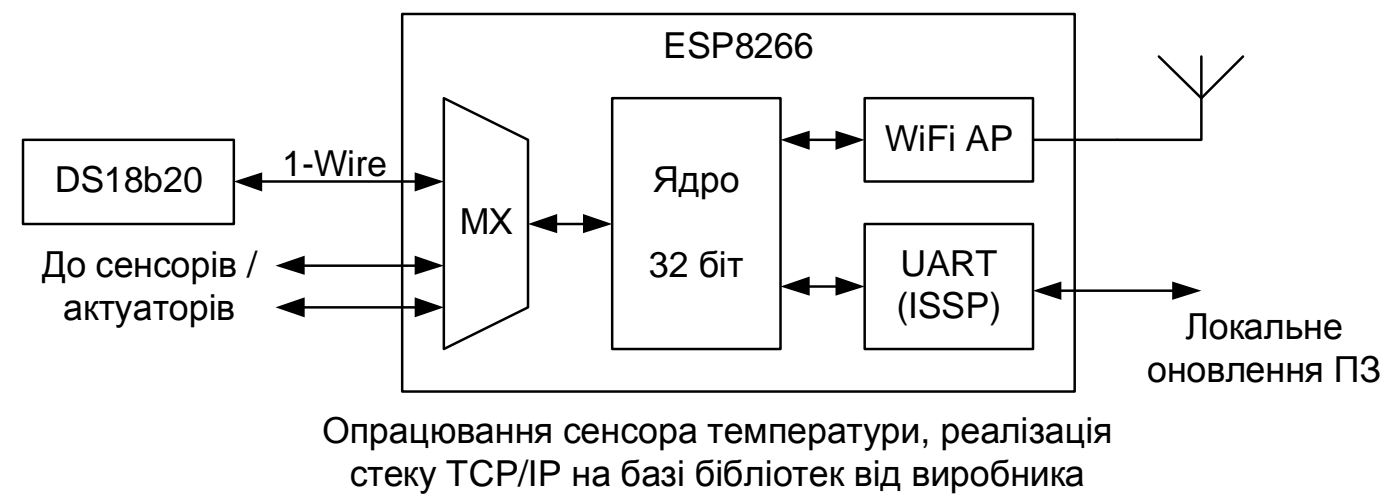

Puс. 9. ТКПС на основі WiFi модуля та сенсора температури

Для організації мережі було обрано WiFi модуль на базі мікроконтролера ESP8266 виробництва Espressif Systems. Модельний ряд виробника модулів є достатньо широким. Функціональні можливості всіх різновидів WiFi модуля ESP8266 є подібними та відрізняються між собою лише кількістю додаткових ліній вводу-виводу, які є доступними користувачу. Ці модулі підтримують стандарти WiFi IEEE $802.11 \mathrm{~b} / \mathrm{g} / \mathrm{n}$. Компанія-виробник позиціонує ці модулі для роботи з стороннім мікроконтролером. Організація зв'язку між модулем ESP8266 та зовнішнім мікроконтролером здійснюється через UART-інтерфейс за допомогою АT-команд.

Які сенсор обрано сенсор температури DS18B20, який для зв'язку з мікроконтролером використовує шину 1-Wire. Цей сенсор має діапазон вимірюваної температури від $-55^{\circ} \mathrm{C}$ до $+125^{\circ} \mathrm{C}$. Точність вимірювання температури в діапазоні від $-10{ }^{\circ} \mathrm{C}$ до $+85{ }^{\circ} \mathrm{C}- \pm 0.5{ }^{\circ} \mathrm{C}$. Програмована роздільна здатність термометра 9-12 розрядів.

Цифровий термометр 3 інтерфейсом 1-Wire під’єднується до незадіяних виводів загального призначення (GPIO) мікроконтролера ESP8266, на цих виводах програмним шляхом емулюється інтерфейс 1-Wire. Перепрограмування мікроконтролера ESP8266 відбувається через UART-інтерфейс, який також доступний для вводу/виводу даних.

Прошивка модуля WiFi була замінена на альтернативну (NodeMcu), альтернативна версія прошивки характерна наявністю інтерпретатора скриптової мови програмування LUA. Цей вибір був зумовлений наявністю великої кількості адаптованих бібліотек для роботи з різноманітними інтерфейсами та сенсорами. Перепрограмування модуля відбувалось в середовищі ESPlorer.

У роботі використано бібліотеки: для емуляції шини 1-Wire, для керування виводами (GPIO), для використання WiFi-iнтерфейсу, для реалізації стеку TCP/IP. Ці бібліотеки є доступними для використання й не потребують ліцензування.

Алгоритм роботи ТКПС наведено на рис. 10.

Після вмикання WiFi-модуль переходить в режим точки доступу і створює нову WiFi-мережу. Щоб абоненти, які будуть приєднуватись до цієї мережі, не налаштовували ії вручну, було створено DHCP сервер для організації роздачі IP-адрес. Дані з мікроконтролера можна отримати через UART-інтерфейс або через програмно реалізований TCP-інтерфейс. Тож для обміну повідомленнями було створено ТCP-сервер, і поверх нього створено Web-сервер. Коли абонент WiFi-мережі виконує запит до TCP-сервера, запит проходить через Web-сервер, відбувається вимірювання за допомогою сенсора температури.

Після отримання даних від сенсора температури формується відповіді для абонента. У відповідь генерується веб-сторінка, на якій відображено поточне значення температури. Після завершення сеансу зв' язку з абонентом мережі ТСР сервер весь час знаходиться в очікуванні нового сеансу зв' язку. 


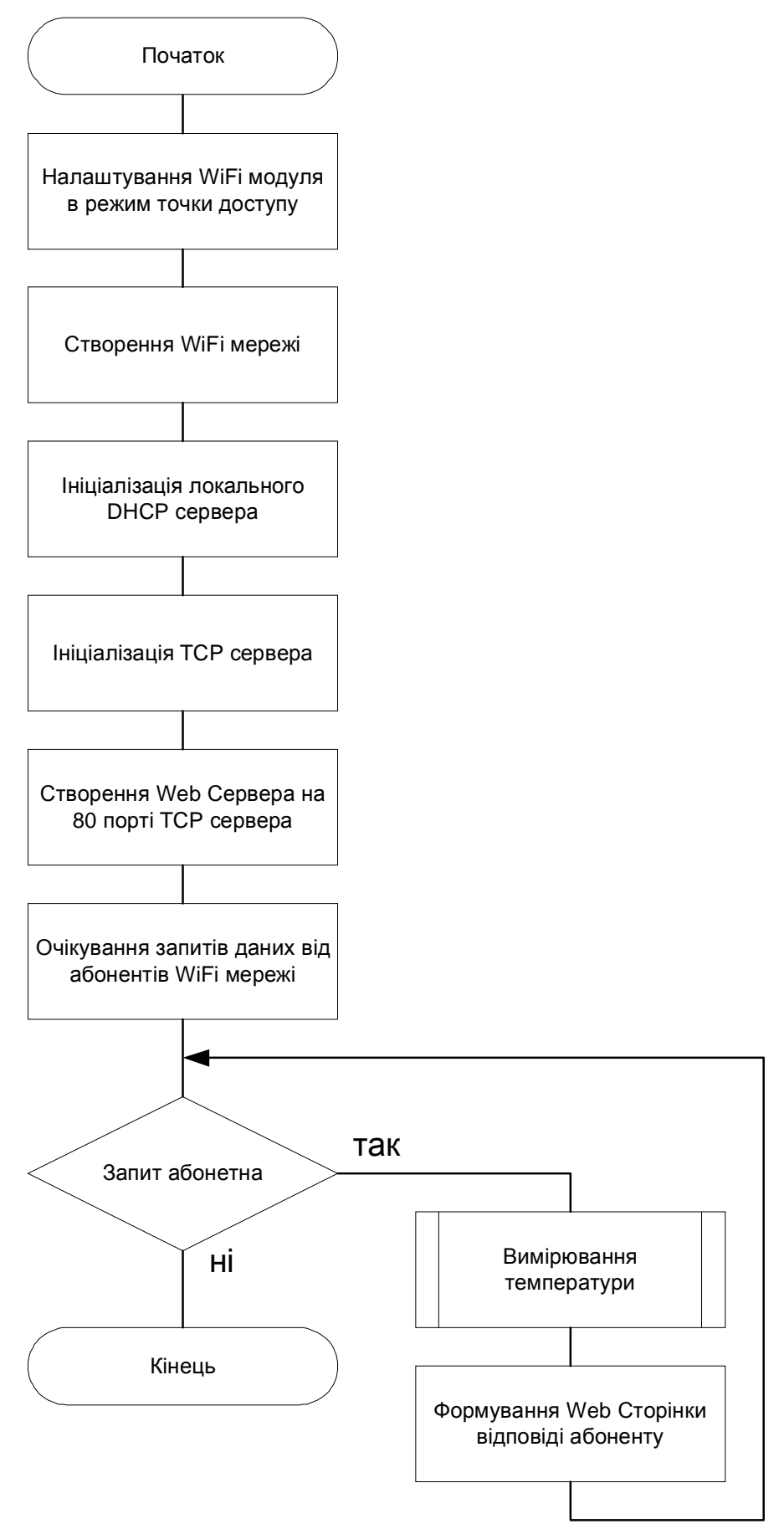

Рис. 10. Алгоритм роботи ТКПС на основі

WiFi-модуля та датчика температури

Така реалізація ТКПС характерна тим, що задіяно мінімальну кількість компонентів, а реалізація всієї роботи зосереджена на внутрішніх ресурсах WiFi-модуля ESP8266. Оновлення програмного забезпечення відбувалось через UART-інтерфейс. Програмну реалізацію алгоритму роботи для цього модуля виконано мовою LUA.

\section{Висновки}

Основними критеріями при формуванні структури ТКПС є обчислювальна складність алгоритмів первинного опрацювання даних та інтенсивність інформаційних потоків, що проходять через нього. Запропоновані базові структурні рішення ТКПС забезпечують розв'язання переважної більшості прикладних задач у ієрархічних Ethernet-орієнтованих КФС. 
За низької обчислювальної складності алгоритмів обробки даних та низької інтенсивності інформаційного обміну рекомендується реалізація ТКПС у вигляді поєднання мікроконтролера 3 інтерфейсним мостом UART-Ethernet або UART -WiFi.

Під час розроблення низькобюджетних безкабельних КФС доцільно звернути увагу на міст UART - WiFi на базі SoC ESP8266 від Espressif.

Універсальнішим рішенням є застосування модуля UART - Ethernet/WiFi HLK-RM04, який забезпечує підтримку двох типів мережних інтерфейсів та двох незалежних асинхронних послідовних портів.

За необхідності виконання складних та ресурсоємних алгоритмів опрацювання даних доцільно використовувати одноплатні мікроЕОМ з інтегрованими мережними інтерфейсами наприклад, серію продуктів Raspberry Рі або їхні функціональні аналоги.

За необхідності індустріального виконання ТКПС можливим рішенням може бути використання стандартних промислових комп'ютерів, хоча це суттєво збільшить вартість КФС.

1. Мельник А. О. Кіберфізичні системи: проблеми створення та напрями розвитку / А. О. Мельник // Вісник Національного університету “Львівська політехніка”. - 2014. - № 806 : Комп'ютерні системи та мережі. - С. 154-161. 2. Мельник А. О. Багаторівнева базова платформа кіберфізичних систем // Кіберфізичні системи: досягнення та виклики. // Матеріали першого наукового семінару, Львів, 2015. - С. 5-15. 3. Мельник А. О. Інтеграція рівнів кіберфізичної системи / А. О. Мельник // Вісник Національного університету “Львівська політехніка”. Комп'ютерні системи та мережі. - 2015. - № 830. - С. 61-67. 4. Міюшкович Є. Г. Телекомунікаційні інтерфейси кіберфізичних систем: концепиія застосування / С. Г. Міюшкович, Я. С. Парамуд // Кіберфізичні системи досягнення та виклики : матеріали I Наукового семінару, 25-26 червня 2015 року, Львів I Національний університет “Львівська політехніка”. - Львів : НВФ “Українські технологіі”, 2015. C. 28-36. 5. Міюшкович С. Г. Особливості класифікаиії та застосування телекомунікаційних інтерфейсів у кіберфізичних системах / С. Г. Міюшкович, Я. С. Парамуд // Вісник Національного університету “Львівська політехніка”. Комп'ютерні системи та мережі. - 2015. - № 830. C. 106-115.

Наукові результати, подані у цій статті, було отримано в рамках дослідницького проекту ДБ/КІБЕР з реєстраційним номером 0115U000446, 01.01.2015 - 31.12.2017, фінансово підтриманим Міністерством освіти та науки України. 